\title{
Adoption of Regular Bearing in Mango over Biennial Bearing
}

\author{
J. S. Shivran ${ }^{1^{*}}$, M. L. Jat ${ }^{2}$, R. K. Jat ${ }^{3}$ and Asha Jat ${ }^{4}$ \\ ${ }^{1}$ Department of Horticulture, GBPUA \& T, Pantnagar, Uttarakhand-263145, India \\ ${ }^{2}$ Department of Horticulture, CCS HAU,Hisar, Haryana, India \\ ${ }^{3}$ Department of Fruit Science, SDAUJagudan, Mehsana, Gujarat, India \\ ${ }^{4}$ Department of Horticulture, Agriculture University, Jodhpur, Rajasthan, India \\ *Corresponding author
}

K e y w o r d s
Regular bearing,
mango, pruning,
flowering

\section{A B S T R A C T}

The alternate bearing in mango trees as well as in other fruit species is a main concern for orchard profitability. Alternate bearing in mango appeared to be related to complex relationships between vegetative and reproductive growths and it is varied according to the cultivar. Flowering is the main event that set the stage for mango production each year. For the attaining the fruit flower initiation is very important and it is very complex phenomena in mango. In mango trees flowering is make them especially challenging for physiologists, breeders, and growers. North, east and central Indian commercial cultivars showed the biennial bearing is very serious problem, while most of the south Indian varieties bear regularly. Biennial bearing in mango trees cause by the different factors like, $\mathrm{C}: \mathrm{N}$ ratio, hormonal balance, climatological factors etc. Therefore, different control measures for the biennial bearing are application of different chemicals, smudging, pruning etc. most widely used in view of its high potential mango production.

\section{Introduction}

The biennial bearing habit of mango (Mangifera indica L.) is one of the major hurdles for its commercial cultivation for getting higher productivity. This cropping problem is entirely an inherent problem of the flowering physiology which is exclusively different from the problems of unfruitfulness. Biennial bearing term is synonymous to 'alternate bearing' which denotes yield variation in alternate years i.e. a year of optimum or heavy fruiting is followed by a year of poor or no fruiting.

During a good year, a tree can be loaded with bumper yield; however, crop quality fluctuates from year to year, so that in the year following a good crop, there are relatively few fruits which affect the overall crop production (Monselise and Goldschmidt, 1982). Irregular bearing term does not imply 
variation in yield in alternate years. This term imply that cropping does not follow a systematic pattern, i.e. an optimum crop is obtained only once in a number of years. Such behaviour is largely due to lack of proper orchard management practices. The degree of bienniality in the cropping of some south Indian mango cultivars and hybrids like the highest mean yield and week bienniality was found in the cultivar Neelashan. However, alternation is also observed at the branch level, emphasizing a clear branch functional autonomy (Lauri et al., 1995). Souza et al., (2002) observed that within a species, alternate bearing can be more or less pronounced depending on the cultivars in mango.

\section{Factors responsible for biennial bearing}

Several factors like, age and size of shoots, climatological factors, carbon/ nitrogen ratio and hormonal balance have been responsible for biennial bearing in mango fruit plants. These factors are described below as;

\section{Age and size of shoots}

Growth in mango takes place in different flushes, which vary in different parts of the country. Early initiation and cessation of growth, followed by a definite dormant period, will helps the shoots to attain proper physiological maturity which is essential for fruit-bud initiation. In the case of regular bearing cultivar Rumani, December emerged shoots are capable of producing the flower buds in the following February. However, the growth of mango shoots is purely a varietal feature and fruit-bud differentiation in regular bearing varieties is an annual feature. In biennial bearing varieties, it is governed by 'on' and 'off' year phase of the trees rather than by the time of origin and cessation of growth of shoots. In an 'on' year, shoots of any size or maturity differentiate flower buds whereas in an 'off' year, even the shoots of requisite size and maturity fail to flower.

\section{Carbon / nitrogen ratio}

That irregular bearing in mango was caused by nutritional deficiency, especially by nitrogen. In fruit plants, nitrogen and carbohydrate reserves play important role in flower bud initiation, even if these do not form the primary cause of the phenomenon of biennial bearing. It is quite probable that an accumulation of these compounds may create favourable conditions for the synthesis and action of the substances responsible for flowering. The accumulation of these compounds may create a favourable condition for the synthesis and action of the substances actually responsible for flower induction in these plants. There was an increased accumulation and metabolism of carbohydrates, proteins and amino acids constituents in the mature plants compared with the juvenile plants (Davenport, 1997). The translocation of phosphorus is involved in controlling the alternate bearing in mango.

\section{Hormonal balance}

Biennial bearing problem in mango appears to be closely associated with the fruit development process and the inhibitory influence of the developing fruits on vegetative growth. Higher levels of auxin like substances and an inhibitor (similar to ABA) and lower levels of Gibberellin $\left(\mathrm{GA}_{3}\right)$ like substances are vital for a floriferous shoots in mango. The inverse relationship between the level of endogenous inhibitor in the shoot and vegetative growth. They are also suggested that higher inhibitor content promotes flowering in mango. Agrawal et al., (1980) described cytokinine-like substances isolated from stem tips of an alternate-bearing cultivar in 'on' and 'off' years. 
The estimated levels of gibberellins in apical buds for 6 months prior to the flowering season were reported to be higher in the 'off' year than in the 'on' year of an alternatebearing cultivar (Pal and Ram, 1978).

\section{Climatological factors}

Adverse climatic conditions like rainfall, high humidity and low temperature sometimes convert an 'on' year into 'off' year directly or by promoting the incidence of diseases like powdery mildew and anthracnose. Frequent frost or low temperatures during the flowering period adversely affect the fruit set, thereby turning an 'on' year into a year of low or no production crop. Chen et al., (1999) reported that the temperature is considered to be key environmental factor, with low temperatures $\left(19^{\circ} \mathrm{C}\right.$ in day and $13^{\circ} \mathrm{C}$ in night) favourable for fruit bud differentiation.

\section{Cultural practices}

The earlier reports that biennial bearing problem is far most part a nutritional one appears to be wrong because liberal manuring and irrigation given to the 20yearsold biennial bearing trees failed to induce regular cropping. Thus, it is evident that while nutritional requirements of the fruit trees must be met for optimum performance of the trees, biennial bearing cannot be overcome by the addition of nutrients.

\section{Crop load}

Generally, moderate blossoming is one of the chief conditions of annual fruit bearing in fruit trees. The number of fruits retained till harvest is a varietal feature. The total number of fruits that are harvested is important because of their deleterious influence on the production of new shoots and their subsequent fruit-bud differentiation. Therefore, the fruit load appears to be the main conditioning factor for 'on' or 'off' year in mango. The potential of shoot to form flower buds will depend on the floriferous condition of the tree, which in turn will be determined by the amount of fruit load carried by the tree in the previous year (Singh, 1971).

\section{Control measures for biennial bearing in mango}

Different control measures are used for the implying the regular bearing in mango. These control measures are described below as;

Proper upkeep and maintenance of orchards.

Deblossoming is a more severe form of fruit thinning, employed to conserve the reserves of the shoots which could otherwise be depleted later on in the development of fruits. Deblossoming of the panicles with NAA @ 200ppm during 'on' year effective for the controlling biennial bearing in mango. Majumder et al., 1976 reported that the alternate bearing in mango reduced by the removal axillary panicles. The partial or complete removal of flowers in the 'on' year increases flowering the next year.

\section{Chemical regulation}

Ethephon has also been successful use in India for increasing flower intensity of mango cultivars Langra and Dashehari during off years (Chadha and Pal, 1986). Chen, 1987 described precocious bud break and flowering of mango shoots in response to an early October application of 100 ppm 6- Benzyl amino purine (6-BA). The paclobutrazol induced enhancement in $\mathrm{C}: \mathrm{N}$ ratio has been reported in mango consistently higher production of total sugars and reducing sugars with peak availability at bud burst in apical buds (Upreti et al., 2014). Besides reducing the gibberellin biosynthesis, PBZ enhances the ABA content. 
PBZ induced increase in ABA content could be due to the modification in the isoprenoid pathway which is common for ABA and gibberellin biosynthesis (Upreti et al., 2013).Potassium nitrate is currently recommended in the Philippines for inducing uniform flowering and for the production of off-season fruits in the 'Pico' and 'Carabao' cultivars (Madamba, 1978).Davenport (2003) reported that bud break was initiated three months later by a foliar application of $\mathrm{KNO}_{3}$ in weakly inductive condition (during warm temperature condition) maximum response was observed at about four weeks.

Plant growth retardants have been evaluated to stimulate early or more intense flowering, especially in the 'off' year of alternatebearing cultivars (Davenport and NúñezElisea, 1997).The efficacy of daminozide and cycocel for increasing flowering in the 'off' season of alternate-bearing cultivars has been studied (Maiti et al., 1972; Rath and Das, 1979; Rath et al., 1982), together with their ability to stimulate early flowering (Suryanarayana and Rao, 1977; Chen, 1985).

\section{Smudging}

Smudging is an early commercial method for inducing flowering in mango (Wester, 1920).Sen and Mallik, 1947 reported that smudging has a stimulating effect on growth, but the nature of growth, vegetative or reproductive, depends on other factors and concluded that smudging can induce flowering only if the shoot is in condition to flower in mango cultivar Langra.

\section{Pruning}

In mango trees, pruning is necessary to control the canopy size and to produce high quality marketable fruits by facilitating better ventilation, high penetration of sunlight, easy application of plant protection chemicals and ease in harvesting (Burondkar et al., 1997; Gross, 1996).Pruning play an important role in mango trees like encouraging the branching of young trees particularly in cultivars which do not branch readily on their own, stimulating the development of new shoots and maintaining the tree size (Oosthuyse, 1994).Tip pruning forces a synchronized flush from pruned stems, which results in synchronized flowering in Keitt mango (Davenport et al., 2006).

The age of the last flush is the dominant factor regulating flowering of mango. Stems must be generally about 4 to 5 months to be able to induce for flowering in the next year (Davenport, 2003).Pruning is effective for early and higher accumulation of reserves by enhancing uniform post-harvest flushing and reduces flowering variation (Oosthuyse, 1994).

\section{Growing regular bearing cultivars}

Totapuri, Rumani, Neelum and almost all hybrids of mango are having regular bearing nature. However, two cultivars, Neelum and Totapuri, which are regular bearers, have been extensively used as the parents in a hybridization programme to transfer the regular bearing habit to hybrids. Neelum has been observed to be a good combiner and has contributed to the evolution of many regular bearing Indian hybrid cultivars. The regular bearing Florida cultivars i.e. 'Tommy Atkins','Keitt', etc. are also have potential as parents.

It is apparent that floral initiation in trees is controlled by a range of factors which may include environmental factors, developmental issues and other interactions with vegetative growth and PGRs. for flowering in shoots high level of starch, some auxin like regulators and inhibitors and a low level of gibberellins may be seemed favourable. 
Maintain of regular bearing in mango is necessary not only for yield sustainability but also for yield increase. Use of some plant growth regulator (paclobutrazol), shoot pruning, use of fruit set chemicals etc. are found to be the most promising approaches for ensuring flowering and enhancing fruit yield under commercial cultivation.

\section{References}

Agrawal, A., Ram, S. and Garg, G.K. (1980). Endogenous cytokinins of mango (MangiferaindicaL.) shoot tips and their significance in flowering. Indian Journal of ExperimentalBiology,18: 504-509.

Burondkar, M.M., Gunjate, R.T., Magdum, M.B., Govekar, M.A. and Waghmare, G.M.(1997).Increasing productivity of mango orchards by pruning and application of paclobutrazol.Acta Hort., 455: 367-74.

Chadha, K.L. and Pal, R.N. (1986).MangiferaindicaL. In: Halevy, A.C. (ed.) CRC Handbook of Flowering, Vol. 5: 211-30. CRC Press, Boca Raton, Florida

Chen, J.Z., Zhao, H., Chen, J.L. and Zhao, H.Y.(1999).Advances in research on flowerbud-differentiation in mango.South China Fruits, 28(2): 3435 .

Chen, W.S. (1985). Flower induction in mango (MangiferaindicaL.) with plant growthsubstances.

Proceedings

National Science Council Part B, Life Sciences (Republicof China), 9: 9-12.

Chen, W.S. (1987). Endogenous growth substances in relation to shoot growth and flower bud development of mango.J. Amer. Soc. Hort. Sci., 112: 360-363.

Davenport, T.L. and Nunez-Elisea, R. (1997). Reproductive physiology. In: Litz, R.E. (ed.)The Mango: Botany, Production and Uses.CAB International, Wallingford, UK,pp. 69-146.

Davenport, T.L.(2003). Management of flowering in tropical and subtropical fruit tree species.Hort. Sci., 38: 13311335.

Davenport, T.L., Nunez-elisea, R.(1997).Reproductive physiology. In: Litz RE (ed), The Mango, Botany, Production and Uses.CAB International, Wallingford Oxon. pp. 69-146.

Davenport, T.L., Ying Z., Kulkarni V. and White T.L.(2006). Evidence for a translocatableflorigenic promoter in mango.Sci. Hort., 110: 150-159.

Gross, G.R.(1996). Pruning of mango to increase yield.Acta Hort., 455: 538-542.

Lauri, P.E., Térouanne, E., Lespinasse, J.M., Regnard, J.L. and Kelner, J.J. (1995). Genotypic differences in the axillary bud growth and fruiting pattern of apple fruiting branches over several years An approach to regulation of fruit bearing. Sci. Hort. 64:265-281.

Madamba, J.C.(1978). The Philippines recommends for mango. Philippine Council for Agriculture and Resources Research.

Maiti, S.C., Basu, R.N. and Sen, P.K. (1972). Chemical control of growth and floweringin Mangiferaindica $\mathrm{L}$. ActaHorticulturae, 24: 192-195.

Majumder, P.K., Sharma, D.K., Singh, M.P. and Singh, R.N. (1976). Improve productivityof malformed mango trees. Journal ofIndian Horticulture, 20: 7-8.

Monselise, S.P. and Goldschmidt, E.E. (1982). Alternate bearing in fruit trees. Hortic. rev., 4: 128-173.

Oosthuyse, S.A., (1994). Pruning of sensation mango trees to maintain their size and effect uniform and later flowering. South African mango grower's Assoc., Year book. 14:1-5.

Pal, S. and Ram, S. (1978). Endogenous gibberellins of mango shoot-tips and 
their significance in flowering. ScientiaHorticulturae, 9: 369-379.

Rath, S. and Das, G.C. (1979).Effect of ringing and growth retardants on growth and flowering of mango.ScientiaHorticulturae, 10: 101104.

Rath, S., Das, G.C. and Singh, R.L. (1982).Manipulation of flowering in mango by forcingthe dormant buds.Bangladesh Horticulture, 10: 39 41.

Sen, P.C. and Mallik, P.C. (1947).Effect of smudging on Mango.Indian J. Hort., 5 (2): 29-34

Singh, L.B. (1971). The mango; Botany, cultivation and utilization. Leonard Hill Ltd., London.

Souza, M.P., Queiroz, M.A., Possídio, E.L., Pereira, F.A. and Nunes, R.F.M. (2002).Study of flowering and alternate bearing of mango varieties in the Sao Francisco Valley.Acta Hort., 645:353-
358.

Suryanarayana, V. and Rao, V.N.M. (1977). Ascorbic acid changes in shoots of mango cv.Mulgoa as affected by growth retardants in relation to flowering. Indian Journal ofPlant Physiology,20: 88-90.

Upreti, K.K., Reddy, Y.T.N., Shivuprasad, S.R., Bindu, G.V., Jayaram, H.L. and Rajan, S.(2013). Hormonal changes in response to paclobutrazol induced early flowering in mango cv. Totapuri. Sci. Hort., 150: 414-418.

Upreti, K.K., Shivuprasad, S.R., Reddy, Y.T.N. and Rajeswara, A.N.(2014).Paclobutrazol induced changes in carbohydrates and some associated enzymes during floral initiation in mango (Mangiferaindica L.) cv. Totapuri. Indian J. Pl. Physiol., 19: 317- 323.

Wester, P.J. (1920).The mango.Philipp. Bur. Agric. Bull. pp. 18.

\section{How to cite this article:}

Shivran. J. S., M. L. Jat, R. K. Jat and Asha Jat. 2020. Adoption of Regular Bearing in Mango over Biennial Bearing. Int.J.Curr.Microbiol.App.Sci. 9(05): 149-154. doi: https://doi.org/10.20546/ijcmas.2020.905.016 